\title{
MANAJEMEN RISIKO OPERASIONAL PADA LEMBAGA AMIL ZAKAT NASIONAL'
}

\author{
Muhammad Fitrahuddin Ajmal Nazir \\ Departemen Ekonomi Syariah - Fakultas Ekonomi dan Bisnis - Universitas Airlangga \\ Email: vdinsiadin@gmail.com \\ Muhammad Nafik Hadi Ryandono \\ Departemen Ekonomi Syariah - Fakultas Ekonomi dan Bisnis - Universitas Airlangga \\ Email: muhammadnafik@feb.unair.ac.id
}

\begin{abstract}
:
The purpose of this study is to know how the national zakat institution manage their operational risk. Things that needs to be reviewed in the operational risk management based on the phenomenon that occurs in the research objects. The objects of this research is three national zakat institution with head office in Surabaya, which three national zakat institution is Yatim Mandiri, Nurul Hayat and YDSF. This research uses qualitative method with case study approach. After the interview, the results of the study were analyzed using descriptive data analysis techniques. The results of research conducted by researchers to three respondents, that operational risk management already performed by three national zakat institution based on their own way. There are 14 risks that identified. How the national zakat institution manage their risks depends on experiences of each national zakat institution itself.
\end{abstract}

Keywords: Risk, Zakat, Operational Risk Management, National Zakat Institution

\section{PENDAHULUAN}

Kewajiban seorang muslim dalam menunaikan zakat tidak kalah pentingnya dengan kewajiban menunaikan sholat, seperti firman Allah dalam surat AlBaqarah ayat 43 :

43. "Dan dirikanlah shalat, tunaikanlah zakat, dan rukuklah beserta orang-orang yang rukuk."

Zakat itu sendiri diperuntukkan bagi delapan kelompok yang berhak menerimanya diantaranya ialah Fakir, Miskin, Amil, Mualaf, Hamba Sahaya, Gharim, Fisabilillah, serta Ibnu Sabil berdasarkan pada firman Allah dalam surat At-Taubah ayat 60 :

60. "Sesungguhnya zakat-zakat itu, hanyalah untuk orang-orang fakir, orangorang miskin, pengurus-pengurus zakat, para mu'allaf yang dibujuk hatinya, untuk (memerdekakan) budak, orang-orang yang berhutang, untuk jalan Allah dan untuk mereka yuang sedang dalam perjalanan, sebagai suatu ketetapan yang diwajibkan Allah, dan Allah Maha Mengetahui lagi Maha Bijaksana."

BPS memandang kemiskinan sebagai ketidakmampuan dari sisi ekonomi untuk memenuhi kebutuhan dasar makanan dan bukan makanan yang diukur dari sisi pengeluaran. Jadi Penduduk Miskin adalah penduduk yang memiliki rata-rata pengeluaran perkapita perbulan dibawah garis kemiskinan.

Zakat rupanya dapat menjadi alternatif dalam mengurangi jumlah kemiskinan di suatu wilayah dengan adanya fakir dan miskin dalam kelompok

\footnotetext{
${ }^{1}$ Jurnal ini merupakan bagian dari skripsi yang ditulis oleh Muhammad Fitrahuddin Ajmal Nazir, NIM: 041411431151 , yang diuji pada 13 Juli 2018.
} 
Nazir, et al/Jurnal Ekonomi Syariah Teori dan Terapan Vol. 6 No. 11 November 2019: 2236-2251; MANAJEMEN RISIKO OPERASIONAL PADA LEMBAGA AMIL ZAKAT NASIONAL

yang berhak menerima zakat, di Indonesia pihak yang berhak mengelola dana zakat ialah Badan Amil Zakat Nasional (BAZNAS), Lembaga Amil Zakat (LAZ), serta Unit Pengelola Zakat (UPZ).

Badan Amil Zakat Nasional (BAZNAS) merupakan badan resmi dan satu-satunya yang dibentuk oleh pemerintah berdasarkan Keputusan Presiden RI No. 8 Tahun 2001 yang memiliki tugas dan fungsi menghimpun dan menyalurkan zakat, infaq, dan sedekah (ZIS) pada tingkat nasional, Lembaga Amil Zakat yang selanjutnya disingkat LAZ adalah lembaga yang dibentuk masyarakat yang memiliki tugas membantu pengumpulan, pendistribusian, dan pendayagunaan zakat yang selanjutnya apabila telah bersekala nasional dan telah mendapat rekomendasi dari BAZNAS maka akan disebut Lembaga Amil Zakat Nasional (LAZNAS). Peneriamaan dan penyaluran zakat oleh BAZNAS setiap tahun pun mengalami peningkatan, berikut data penerimaan dan penyaluran dana zakat mulai tahun 2012 hingga 2016 :

Tabel 1.

Penerimaan dan Penyaluran Dana Zakat pada Tahun 2012-2016

\begin{tabular}{|l|l|l|}
\hline Tahun & \multicolumn{1}{|c|}{ Penerimaan } & \multicolumn{1}{|c|}{ Penyaluran } \\
\hline 2012 & $\mathrm{Rp}$ & $\mathrm{Rp}$ \\
& 40.387 .972 .149 & 36.019 .079 .930 \\
\hline 2013 & $\mathrm{Rp}$ & $\mathrm{Rp}$ \\
& 50.741 .735 .215 & 45.068 .566 .496 \\
\hline 2014 & $\mathrm{Rp}$ & $\mathrm{Rp}$ \\
& 69.865 .506 .671 & 64.265 .141 .159 \\
\hline 2015 & $\mathrm{Rp}$ & $\mathrm{Rp}$ \\
& 82.272 .643 .293 & 66.766 .033 .369 \\
\hline 2016 & $\mathrm{Rp}$ & $\mathrm{Rp}$ \\
& 97.637 .657 .910 & 67.727 .019 .807 \\
\hline
\end{tabular}

Sumber: Laporan Keuangan BAZNAS
Biaya operasional

BAZNAS

dibebankan pada anggaran pendapatan dan belanja negara serta Hak Amil, hal ini didasarkan pada Peraturan Pemerintah Nomor 14 Tahun 2014 tentang Pengelolaan Zakat, berbeda dengan LAZNAS yang biaya operasionalnya tidak ditanggung oleh anggaran pendapatan dan belanja negara, sehingga kebijakan dalam menentukan besarnya biaya operasional serta sumber biaya operasional antar LAZNAS berbeda antara LAZNAS satu dengan lainnya berdasarkan kebijakan masing masing, Biaya Operasional menurut Jusuf (2008:33) adalah biayabiaya yang tidak berkaitan langsung dengan produk perusahaan teteapi berhubungan dengan aktivitas operasional perusahaan sehari-hari. Secara umum, biaya operasional dapat diartikan sebagai biaya yang terjadi dalam kaitannya dengan operasi yang dilakukan perusahaan dan diukur dalam satuan vang. Biaya operasi sering disebut juga sebagai biaya usaha.

Manusia mengalami ketidakpastian, ketidakpastian tersebut diantaranya kapan hari kiamat akan datang, kapan hujan akan turun, apa yang ada dalam rahim seorang ibu, ketidakpastian akan hasil dari usaha yang dilakukan, serta ketidakpastian akan kematian, sesungguhnya semua yang terjadi merupakan kehendak dari Allah, seperti dalam surat Al-Luqman ayat 34: 
34. Sesungguhnya Allah, hanya pada sisiNya sajalah pengetahuan tentang Hari Kiamat; dan Dialah Yang menurunkan hujan, dan mengetahui apa yang ada dalam rahim. Dan tiada seorangpun yang dapat mengetahui (dengan pasti) apa yang akan diusahakannya besok. Dan tiada seorangpun yang dapat mengetahui di bumi mana dia akan mati. Sesungguhnya Allah Maha Mengetahui lagi Maha Mengenal.

Ketidakpastian yang ada akan menimbulkan risiko, risiko itu sendiri adalah adalah suatu akibat yang akan dihadapi atas pilihan yang mengandung ketidakpastian yang berpotensi menghasilkan dampak negatif yang dapat merugikan pihak pengambil keputusan (Wahyudi dkk, 2013:4)

Risiko senantiasa melekat pada usaha-usaha yang dilakukan, tanpa terkecuali usaha yang dilakukan oleh Lembaga Amil Zakat Nasional, salah satu risiko yang ada adalah risiko operasional dimana risiko ini berkaitan dengan dengan kesalahan dalam pengelolaan internal, kesalahan sumber daya manusia, kegagalan pada sistem dan kejadiankejadian eksternal yang dapat memepengaruhi operasional lembaga pengelolaan zakat, oleh karenanya manajemen risiko dirasa perlu dilakukan untuk mengantisipasi segala kemungkinan yang akan terjadi pada usaha pengelolaan zakat oleh Lembaga Amil Zakat Nasional .

\section{LANDASAN TEORI}

Undang-undang republik Indonesia Nomor 23 tahun 2011 tentang pengelolaan zakat pada pasal 1 ayat 8 menyebutkan bahwa lembaga amil zakat adalah "Lembaga Amil Zakat yang selanjutnya disingkat LAZ adalah lembaga yang dibentuk masyarakat yang memiliki tugas membantu pengumpulan, pendistribusian, dan pendayagunaan zakat.". dalam praktiknya lembaga amil zakat juga melakukan pengelolaan terhadap dana infaq/ sedekah dan dana sosial keagamaan lainnya (DSKL) seperti wakaf.

Menteri Agama Republik Indonesia mengeluarakan regulasi yang mengtaur perihal Lembaga Amil Zakat yaitu Keputusan Menteri Agama Nomor 333 Tahun 2015 tentang pedoman pemberian izin pembentukan lembaga amil zakat, dalam regulasi ini terdapat tiga skala pada Lembaga Amil Zakat yaitu nasional, provinsi, dan kabupaten/ kota. Dalam peraturan tersebut juga menyebutkan bahwa LAZ nasional (LAZNAS) ialah Lembaga Amil Zakat yang sanggup menghimpun zakat, infaq dan sedekah dan dana sosial keagamaan lainnya minimal Rp.50.000.000.000,- (lima puluh milyar rupiah) per tahun, LAZ Provinsi ialah Lembaga Amil Zakat yang sanggup menghimpun zakat, infaq dan sedekah dan dana sosial keagamaan lainnya minimal Rp.20.000.000.000,- (dua puluh milyar rupiah) per tahun, LAZ Kabupaten/ Kota ialah Lembaga Amil Zakat yang sanggup menghimpun zakat, infaq dan 
Nazir, et al/Jurnal Ekonomi Syariah Teori dan Terapan Vol. 6 No. 11 November 2019: 2236-2251; MANAJEMEN RISIKO OPERASIONAL PADA LEMBAGA AMIL ZAKAT NASIONAL

sedekah dan dana sosial keagamaan lainnya minimal Rp.3.000.000.000,- (tiga milyar rupiah) per tahun.

Operasional lemabaga amil zakat didasarkan pada rencana strategis Standar Operasional Prosedur oleh Kementrian Agama Republik Indonesia tahun 2012 secara garis besar meliputi:

1. Sosialisasi

2. Strategi Pengumpulan

3. Pendistribusian dan Pendayagunaan

Ada berbagai macam pengertian mengenai istilah manajemen, R. Tery dalam Amrullah (2004:7) menyatakan bahwa manajemen merupakan suatu proses khas yang terdiri dari tindakantindakan perencanaan, pengorganisasian, penggerakan, dan pengendalian yang dilakukan untuk menentukan melalui pemanfaatan sumber daya manusia dan sumbersumber lainnya. Koontz dan Weihrich (2012:3) menyebutkan bahwa manajemen adalah proses mendesain dan mempertahankan lingkungan dimana individu-individu bekerja secara berkelompok dan efisien untuk mencapai tujuan yang sudah ditetapkan.

Peraturan otoritas jasa keuangan Nomor 18 /POJK.03/2016 tentang penerapan manajemen risiko bagi bank umum pada pasal 1 ayat 2 menyebutkan bahwa risiko adalah "Potensi kerugian akibat terjadinya suatu peristiwa tertentu."

Dalam bidang perbankan islam, definisi risiko adalah suatu akibat yang akan dihadapi atas pilihan yang mengandung ketidakpastian yang berpotensi menghasilkan dampak negatif yang dapat merugikan pihak pengambil keputusan (Wahyudi dkk, 2013:4)

Dari beberapa pengertian di atas dapat disimpulkan bahwa risiko merupakan suatu hal yang belum terjadi dan apabila terjadi dapat menimbulkan kerugian, sesuatu dikatakan risiko apabila memiliki karakteristik yaitu belum terjadi dan apabila terjadi dapat menimbulkan kerugian.

Dalam Islam, risiko merupakan kehendak dari Allah. Segala hal yang terjadi kepada manusia merupakan ketentuan Allah SWT. Seperti dalam firman Allah SWT dalam Al-Quran surat AlLuqman ayat 34 Yang sudah dijelaskan sebelumnya. Wahyudi, dkk (2013: 15) menjelaskan tidak ada satu pun yang bisa menjamin bahwa bisnis yang dijalankan oleh seseorang akan mengalami keuntungan atau kerugian di masa depan. Dengan demikian, risiko itu sendiri merupakan fitrah yang senantiasa melekat dalam kehidupan. Oleh karenanya, Islam tidak mengenal adanya transaksi bisnis yang bebas risiko.

Pesrpektif islam dalam pengelolaan risiko dapat dikaji dari kisah Nabi Yusuf dalam mentakwilkan mimpi sang raja pada masa itu (Hastawa: 2013). Kisah Nabi Yusuf dalam mentakwilkan mimpi sang raja dijelaskan pada Al-Quran surat Yusuf ayat 46 sampai 49 (Hastawa: 2013). Berdasarkan ayat tersebut menunjukkan bagaimana Nabi Yusuf 
mengelola risiko yang akan terjadi pada musim paceklik, yaitu dengan cara menyimpan persediaan makanan pada saat musim subur dan hanya menggunakannya untuk keperluan yang penting, sehingga rakyat dapat bertahan pada saat musim paceklik.

Zakat core principels (ZCP) menjelaskan bahwa risiko operasional pada lembaga zakat mungkin saja mencangkup pada kekacauan yang potensial, kesalahan teknik dari sistem komputer, dan faktor lain yang mungkin mengganggu lembaga zakat pada operasionalnya sehari hari termasuk aspek kepatuhan syariah. Dalam rangka meminimalisir kekacauan yang potensial dan pelanggaran syariah yang potensial, lembaga zakat harus dilengkapi dengan struktur penguasaan yang baik untuk memastikan bahwa tanggungjawab dan akuntabilitasnya dapat terpenuhi. Menurut Triyani dalam Ascarya (2016:10) secara garis besar ada tiga kelompok risiko operasional pengelolaan zakat, antara lain:

1. Pengumpulan Dana Zakat (Dana zakat, Hambatan pengumpulan zakat, Tingkat kepercayaan)

2. Pengelolaan Dana Zakat (Penggunaan dana zakat yang tidak tepat, Waktu penyaluran/distribusi zakat, Lemahnya monitoring amil, Tingkat kepercayaan pada amil, Terhambat kebijakan pemerintah, Lemahnya pelayanan amil)
3. Pendistribusian (Tingkat Kepercayaan pada Amil, Distribusi yang tidak tepat, Hambatan dalam pendistribusian zakat).

Menurut M. Hanafi (2012:94) risiko operasional merupakan tipe risiko yang paling "tua" namun paling sedikit dipahami dibandingkan dengan risiko lainnya. M. Hanafi (2012:94) juga menyatakan Basel II (lembaga yang mengatur perbankan internasional) mendefinisikan bahwa risiko operasional sebagai risiko yang timbul karena kegagalan dari proses internal, manusia, sistem, atau dari kejadian eksternal. Nampak bahwa definisi tersebut mencangkup hal yang sangat luas. Tetapi pengelompokan semacam itu bermanfaat karena memberikan pengetahuan mengenai sumber-sumber risiko operasional. Penjabaran dari definisi tersebut adalah :

1. Kegagalan Proses Internal

Risiko kegagalan proses internal merupakan risiko yang berkaitan dengan kegagalan proses atau prosedur internal organisasi.

2. Risiko kegagalan mengelola manusia (karyawan)

Karyawan merupakan aset penting bagi perusahaan namun juga merupakan sumber risiko operasional bagi perusahaan. Risiko dari karyawan tersebut baik sengaja maupun tidak sengaja.

3. Risiko sistem 
Sistem teknologi bisa memberikan kontribusi yang signifikan bagi organisasi, di lain pihak, sistem tersebut akan memunculkan risiko baru bagi organisasi, jika perusahaan terlalu bergantung pada sistem komputer, misal, maka risiko yang berkaitan dengan kerusakan komputer akan semakin tinggi.

4. Risiko eksternal

Berkaitan dengan kejadian yang bersumber dari luar organisasi dan beraada di luar pengendalian organisasi. Kejadian tersebut biasanya jarang terjadi namun memiliki dampak yang begitu besar.

Berdasarkan beberapa pengertian mengenai risiko operasional dan cakupannya dapat disimpulkan bahwa risiko operasional sangatlah luas, bukan tidak mungkin sifat risiko operasional tersebut mengikuti karakteristik lembaga amil zakat yang akan diteliti nantinya.

$$
\text { Wahyudi, dkk (2013: }
$$

mendefinisikan manajemen risiko adalah sebuah proses, di dalamnya terdapat berbagai tahapan yang saling berkaitan dan berulang untuk saling melengkapi dan menyempurnakan. Sedangkan menurut Kountur (2008:22) Manajemen risiko adalah suatu metode yang biasa digunakan oleh perusahaan untuk melakukan penanganan terhadap risikorisiko yang akan dihadapi oleh perusahaan. M. Hanafi (2012:9) menyatakan bahwa manajemen risiko pada dasarnya dilakukan melalui prosesproses berikut ini.

A. Idientifikasi risiko

Proses manajemen risiko dimulai dengan proses identifikasi risiko, $M$. Hanafi (2012:10) menyatakan Idientifikasi risiko dilakukan untuk mengidientifikasi risiko-risiko apa saja yang dihadapi oleh suatu organisasi.

B. Evalusai dan pengukuran risiko

Tujuan evaluasi risiko adalah untuk memahami karakteristik risiko dengan lebih baik. Jika kita memperoleh pemahaman yang lebih baik, maka risiko akan lebih mudah dikendalikan. Evaluasi yang lebih sistematis dilakukan untuk 'mengukur' risiko tersebut ( $M$. Hanafi, 2012:10). Pengukuran risiko adalah suatu proses untuk menghasilkan apa yang disebut dengan status risiko dan peta risiko (Kountur, 2008:28). Salah satu indikator apakah suatu perusahaan telah melaksanakan manajemen risiko dengan benar dan profesional adalah jika setiap unit di dalam perusahaan memiliki peta risiko dan ada status risikonya (Kountur, 2008:29). Peta risiko adalah gambaran tentang posisi risiko pada suatu peta dari dua sumbu yaitu sumbu vertikal dan sumbu horizontal. Sumbu vertikal menggambarkan probabilitas, sedangkan sumbu horizontal menggambarkan dampak (Kountur, 2008:107).

Alijoyo (2004:53) menjelaskan bahwa suatu entitas dapat menilai risiko 
dengan metodologi kualitatif dan kuantitatif. Sebuah entitas dapat menggunakan matriks penilaian sebagai berikut :

\section{Dampak (severity)}

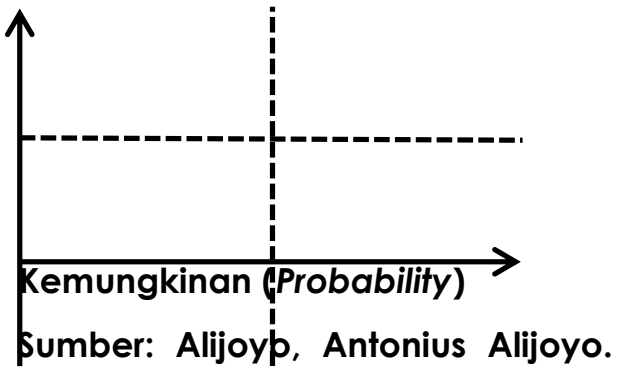

2006.

\section{Gambar 1.}

\section{Matriks Penilaian Risiko}

Metodologi penilaian kualitatif apabila risiko yang terjadi tidak memungkinkan untuk di ukur dalam hitungan metrik, data untuk penilaian kuantitatif tidak tersedia, dan biaya proses penilaian kuantitatif sangat besar. Penilaian kuantitatif membutuhkan model matematis yang membutuhkan kualitas dari data dan asumsi yang mendukung dan paling relevan. Gambar diatas merupakan contoh matriks penilaian risiko dengan pendekatan probability dan severity yang biasa disebut qualitative approach.

C. Pengelolahan risiko

Langkah selanjutnya adalah pengelolaan risiko, apabila M. Hanafi dalam bukunya menyebutkan pengelolaan risiko, Kontur menyebut langkah ini sebagai penanganan risiko. Penanganan risiko bertujuan untuk memberikan usulan apa yang akan dilakukan untuk menangani risiko-risiko yang telah terpetakan (Kountur, 2008:29). Berdasarkan peta risiko yang telah dibuat dapat diketahui strategi penanganan yang sesuai untuk risikorisiko tersebut. Terdapat dua strategi penanganan risiko yaitu preventif dan mitigasi (Kountur, 2008:120).

Sehingga dapat disimpulkan bahwa manajemen risiko adalah serangkaian proses diantaranya yaitu idientidikasi, evaluasi dan pengukuran serta pengelolahan atau penanganan terhadap risiko-risiko yang akan dihadapi.

\section{Metode Penelitian}

Penelitian secara garis besar memiliki dua metode yaitu metode kuantitatif dan metode kualitatif. Berdasarkan rumusan masalah sebelumnya maka metode yang digunakan adalah metode kualitatif. Penelitian ini menggunakan strategi studi kasus. Menurut Yin (2015: 1), studi kasus merupakan strategi yang lebih cocok bila pokok pertanyaan suatu penelitian terkait dengan how atau why, bila peneliti hanya memiliki sedikit peluang untuk mengontrol peristiwa-peristiwa yang akan diselidiki, dan bilamana fokus penelitiannya terletak pada fenomena kontemporer (masa kini) di dalam konteks kehidupan nyata

Yin (2014: 30) menyatakan unit analisis merupakan komponen yang secara fundamental berkaitan dengan masalah penentuan apa yang dimaksud dengan kasus dalam penelitian yang bersangkutan. Unit analisis pada penelitian ini adalah proses manajemen 
Nazir, et al/Jurnal Ekonomi Syariah Teori dan Terapan Vol. 6 No. 11 November 2019: 2236-2251; MANAJEMEN RISIKO OPERASIONAL PADA LEMBAGA AMIL ZAKAT NASIONAL

risiko, yaitu identifikasi risiko, evaluasi dan pengukuran risiko, dan pengelolaan risiko.

Pembatasan dalam penelitian kualitatif lebih didasarkan pada tingkat kepentingan, urgensi, dan feasibilitas masalah yang akan dipecahkan, selain itu juga faktor keterbatasan tenaga, dana, dan waktu. Ruang lingkup dalam penelitian ini difokuskan pada proses manajemen risiko operasional 3 lembaga amil zakat yang memiliki karakteristik serupa dan berada di Jawa Timur.

Data dalam penelitian kualitatif dibagi menjadi dua yaitu data primer dan data sekunder. Data primer adalah data yang berasal dari wawancara dan observasi langsung di lapangan, sehingga bentuk datanya lebih berwujud kata-kata dan tindakan dari objek penelitian. Data primer diperoleh langsung dari sumbernya melalui wawancara. Metode wawancara dilakukan agar peneliti bisa menggali informasi yang lebih mendalam sehingga dapat dipertanggung jawabkan validitas datanya. Sedangkan data sekunder adalah data yang sudah ada yang berkaitan dengan penelitian seperti dokumen. Data sekunder digunakan sebagai data pendukung untuk menambah rincian spesifik dan untuk melengkapi data primer.

Penelitian ini menggunakan teknik triangulasi dalam pemeriksaan keabsahan data. Teknik triangulasi merupakan teknik pemeriksaan yang memanfaatkan sesuatu yang lain. Sugiono (201 1:373-374) membagi teknik triangulasi menjadi tiga macam yaitu triangulasi sumber, triangulasi teknik dan triangulasi waktu. Triangulasi yang digunakan dalam penelitian ini adalah triangulasi sumber, yakni menguji kredibilitas data dengan cara melakukan crosscheck kepada para informan yang diwawancarai, dokumentasi dan observasi langsung.

Setelah dilakukan pengumpulan data dengan menggunakan pendekatan di atas, kemudian dilakukan teknik analisis data. Analisis data dilakukan agar hasil yang diperoleh dapat mudah dibaca dan dipahami sebagai cara untuk menyelesaikan permasalahan penelitian. Secara umum terdapat tiga teknik analisis data, yaitu penjodohan pola, deskriptif, dan analisis deret waktu. Teknik analisis data yang digunakan dalam penelitian ini adalah deskriptif yang bertujuan untuk menganalisis data studi kasus dengan cara mendeskripsikan tentang kasus yang bersangkutan. Yin (2015: 137) menyatakan bahwa kadangkala tujuan asli studi kasus adalah deskriptif.

\section{HASIL DAN PEMBAHASAN}

Peneliti berhasil mewawancarai tiga informan, masing masing dari lembaga amil zakat nasional yang berbeda, ketiga informan tersebut juga memiliki jabatan yang berbeda beda antara satu dengan lainnya, hal ini dikarenakan pada saat peneliti membuat janji wawancara dengan Lembaga Amil Zakat Nasional terkait, Lembaga Amil Zakat Nasional tersebutlah yang menentukan dengan siapa peneliti akan 
melakukan wawancara, hal ini tidak menjadi sebuah permasalahan karena peneliti mengasumsikan bahwa orang yang dipilih oleh pihak Lembaga Amil Zakat Nasional tersebut merupakan informan yang paling berkompeten menjawab pertanyaan-pertanyaan yang sesuai dengan tema penelitian. Informan pertama adalah Ibu Hemi dari Yatim Mandiri, beliau merupakan staff research and development(R\&D). Informan kedua adalah Ibu Tantri dari Nurul Hayat beliau merupakan manager human resource and development (HRD). Informan ketiga adalah Bapak Eko dari Yayasan Dana Sosial Al-Falah (YDSF) beliau merupakan karyawan pada bagian umum.

Zakat Core Principels (ZCP) yang dikelvarkan oleh Bank Indonesia dan Badan Amil Zakat Nasional pada tahun 2016 lalu merupakan dokumen yang secara spesifik di dalamnya menyinggung perihal manajemen risiko pada pengelolaan zakat, sehingga peneliti menggunakan profil risiko pada Zakat Core Principels sebagai acuan, dalam hal ini profil risiko yang digunakan adalah risiko operasional, pada saat wawancara terhadap narasumber mengenai poin adakah regulasi yang digunakan dalam manajemen risiko, atau spesifik mengatur masalah manajemen risiko, ketiga lembaga amil zakat masih belum mengetahui apa itu Zakat Core Principels, adapun acuan masih bersifat umum

Berdasarkan wawancara jelas bahwa ketiga lembaga amil zakat nasional yang diwawancarai masih belum mengetahui apa itu Zakat Core Principels namun telah melakukan manajemen risiko berdasarkan peraturan pada lembaga amil zakat masing-masing, terlepas dari tahu atau tidaknya ketiga lembaga amil zakat dengan Zakat Core Principels setidaknya lebaga amil zakat yang bersangkutan telah melakukan manajemen risiko operasional. Dalam Zakat Core Principels perihal manajemen risiko operasional bawasannya dalam rangka meminimalisir kekacauan yang potensial dan pelanggaran syariah yang potensial, lembaga zakat harus dilengkapi dengan struktur penguasaan yang baik untuk memastikan bahwa tanggungjawab dan akuntabilitasnya dapat terpenuhi. Usaha lembaga amil zakat nasional dalam menghadapi risiko operasionalnya berbeda beda bergantung pada kebijakan masing masing yang diterapkan, berdasarkan wawancara terhadap lembaga amil zakat nasional yang dilaakukan oleh peneliti, bagaimana lembaga amil zakat nasional menghadapi risiko operasional antara yang satu dengan yang lainnya berbeda, hal ini disebabkan karena karakteristik dan kebijakan lembaga amil zakat nasional tersebut yang berbeda beda pula

Berdasarkan landasan teori sebelumnya, prosses manajemen risiko dibagi menjadi tiga tahap yaitu Idientifikasi Risiko, Evaluasi \& Pengukuran Risiko, dan Pengelolaan Risiko. Idientifikasi 
yaitu dimana kita dapat mengetahui risiko apa saja yang akan terjadi, Evalusai dan Pengukuran Risiko yaitu dimana risiko dapat diketahui bagaimana dampak apabila terjadi beserta besarnya kemungkinan terjadinya risiko tersebut, dan pengelolaan risiko adalah bagaimana cara menangani risiko yang telah teridientifikasi sebelumnya.

Berdasarkan wawancara mengenai idientifikasi risiko kepada ketiga narasumber yaitu Ibu Hemi dari Yatim Mandiri, Ibu Tantri dari Nurul Hayat dan Bapak Eko dari YDSF. Terdapat 14 risiko yang telah teridientifikasi dari ketiga lembaga amil zakat nasional tersebut, agar lebih mudah dapat dilihat pada Tabel 2.

\section{Tabel 2.}

Risiko yang Teridentifikasi

\begin{tabular}{|l|l|}
\hline No & Risiko yang Teridientifikasi \\
\hline 1. & Target yang tidak terpenuhi \\
\hline 2. & Kepatuhan syariah tidak terpenuhi \\
\hline 3. & Sistem komputer yang bermasalah \\
\hline 4. & Persaingan dengan LAZNAS lain \\
\hline 5. & Supplier yang terbatas \\
\hline 6. & Cyber error \\
\hline 7. & $\begin{array}{l}\text { Pengajuan cuti yang tidak sesuai } \\
\text { peraturan }\end{array}$ \\
\hline 8. & $\begin{array}{l}\text { Pengajuan dana kesehatan yang } \\
\text { tidak sesuai peraturan }\end{array}$ \\
\hline 9. & $\begin{array}{l}\text { Pengajuan pelatihan karyawan } \\
\text { yang tidak tepat sasaran }\end{array}$ \\
\hline 10. & Prosedur yang tidak berjalan \\
\hline 11. & $\begin{array}{l}\text { Resik, rapi, ringkas, rajin yang tidak } \\
\text { terpenuhi }\end{array}$ \\
\hline 12. & $\begin{array}{l}\text { Pengambilan donasi yang tidak } \\
\text { tepat waktu }\end{array}$ \\
\hline 13. & $\begin{array}{l}\text { Edukasi masyarakat mengenai } \\
\text { zakat yang kurang }\end{array}$ \\
\hline 14. & $\begin{array}{l}\text { Tertinggal dalam mengikuti } \\
\text { perkembangan teknologi }\end{array}$ \\
\hline
\end{tabular}

Sumber : Hasil wawancara
Dari 14 risiko operasional yang telah teridentifikasi apabila digolongkan lebih rinci lagi berdasarkan 4 tipe risiko operasional yaitu ancaman dari luar, kegagalan system, kegagalan mengelola manusia, kegagalan proses internal, maka akan didapatkan pengelompokan sebagai berikut:

Tabel 3.

\section{Risiko Operasional Ancaman dari Luar}

\begin{tabular}{|l|l|}
\hline No. & Risiko Operasional \\
\hline 1. & Pesaingan dengan LAZNAS lain \\
\hline 2. & Cyber error \\
\hline 3. & Supplier yang terbatas \\
\hline 4. & $\begin{array}{l}\text { Edukasi masyarakat mengenai zakat } \\
\text { yang kurang }\end{array}$ \\
\hline
\end{tabular}

Sumber: Pengelompokan Hasil

Wawancara

Dapat diketahui berdasarkan tabel risiko operasional yang berasal dari ancaman luar lembaga amil zakat nasional terdapat 4 risiko yaitu persaingan dengan LAZNAS lain, cyber error, supplier yang terbatas, dan edukasi masyarakat mengenai zakat yang kurang, pada tabel selanjutnya akan dijelaskan pengelompokan risiko operasional yang berasal dari kegagalan sistem.

Tabel 4.

Risiko Operasional Kegagalan Sistem

\begin{tabular}{|l|l|}
\hline No. & Risiko Operasional \\
\hline 1. & Sistem komputer bermasalah \\
\hline 2. & Cyber error \\
\hline 3. & $\begin{array}{l}\text { Tertinggal dalam mengikuti } \\
\text { perkembangan teknologi }\end{array}$ \\
\hline
\end{tabular}

Sumber: Pengelompokan Hasil

Wawancara

Berdasarkan tabel risiko operasional kegagalan sistem dapat diketahui terdapat 3 risiko yang masuk dalam risiko operasional kegagalan sistem 
yaitu sistem komputer yang bermasalah, cyber error dan tertinggal dalam mengikuti perkembangan teknologi. Cyber error seperti yang kita ketahui sebelumnya telah masuk dalam penggolongan risiko operasional ancaman dari luar, cyber error memungkinkan masuk dalam dua penggolongan karena memang karakteristiknya yang dapat digolongkan berdasarkan ancaman dari luar dan kegagalan sistem.

\section{Tabel 5.}

Risiko Operasional Kegagalan Mengelola Manusia

\begin{tabular}{|l|l|}
\hline No. & Risiko Operasional \\
\hline 1. & Target yang tidak terpenuhi \\
\hline 2. & $\begin{array}{l}\text { Kepatuhan syariah yang tidak } \\
\text { terpenuhi }\end{array}$ \\
\hline 3. & $\begin{array}{l}\text { Pengajuan cuti yang tidak sesuai } \\
\text { peraturan }\end{array}$ \\
\hline 4. & $\begin{array}{l}\text { Pengajuan dana kesehatan yang } \\
\text { tidak sesuai peraturan }\end{array}$ \\
\hline 5. & $\begin{array}{l}\text { Pengajuan pelatihan karyawan } \\
\text { yang tidak tepat sasaran }\end{array}$ \\
\hline 6. & $\begin{array}{l}\text { Pengambilan donasi yang tidak } \\
\text { tepat waktu }\end{array}$ \\
\hline
\end{tabular}

Sumber: Pengelompokan Hasil

Wawancara

Risiko operasional yang termasuk kegagalan mengelola manusia berdasarkan tabel adalah target yang tidak terpenuhi, kepatuhan syariah yang tidak terpenuhi, pengajuan cuti yang tidak sesuai peraturan, pengajuan dana kesehatan yang tidak sesuai peraturan, pengajuan pelatihan karyawan yang tidak tepat sasaran dan pengambilan donasi yang tidak tepat waktu. Pada tabel selanjutnya akan dijelaskan risiko operasional yang berhubungan dengan kegagalan proses internal.
Tabel 6.

Risiko Operasional Kegagalan Proses Internal

\begin{tabular}{|l|l|}
\hline No. & Risiko Operasional \\
\hline 1. & Target yang tidak terpenuhi \\
\hline 2. & $\begin{array}{l}\text { Kepatuhan syariah yang tidak } \\
\text { terpenuhi }\end{array}$ \\
\hline 3. & Prosedur yang tidak berjalan \\
\hline 4. & $\begin{array}{l}\text { Resik, rapi, ringkas, rajin yang tidak } \\
\text { terpenuhi }\end{array}$ \\
\hline 5. & $\begin{array}{l}\text { Pengambilan donasi yang tidak } \\
\text { tepat waktu }\end{array}$ \\
\hline 6. & $\begin{array}{l}\text { Tertinggal dalam mengikuti } \\
\text { perkembangan teknologi }\end{array}$ \\
\hline
\end{tabular}

Wawancara

Risiko operasional yang termasuk kegagalan proses internal antara lain target yang tidak terpenuhi, kepatuhan syariah yang tidak terpenuhi, prosedur yang tidak berjalan, resik rapi ringkas rajin yang tidak terpenuhi, pengambilan donasi yang tidak tepat waktu dan tertinggal dalam mengikuti perkembangan teknologi.

Pengukuran risiko menggunakan matriks penilaian risiko dengan pendekatan probability dan severity yang biasa disebut qualitative approach, pada pendekatan ini data yang dibutuhkan adalah seberapa besar kemunkinan (probability) risiko tersebut akan terjadi dan seberapa besar dampak (severity) risiko tersebut apabila tejadi, data telah didapatkan berdasarkan hasil wawancara dimana masing-masing lembaga amil zakat mengurutkan dampak dan kemungkinan risiko yang telah teridenifikasi sebelumnya, selanjutnya risiko yang telah teridentifikasi dan dikelompokkan berdasarkan 4 jenis risiko operasional yaitu ancaman dari luar, 
kegagalan system, kegagalan mengelola manusia dan kegagalan proses internal akan diberi nilai berkaitan dengan kemungkinan dan dampaknya apabila terjadi, data yang akan tersaji berupa 4 matriks pengukuran risiko berdasarkan macam-macam risiko operasional beserta letak 3 lembaga amil zakat pada matriks pengukuran risiko tersebut.

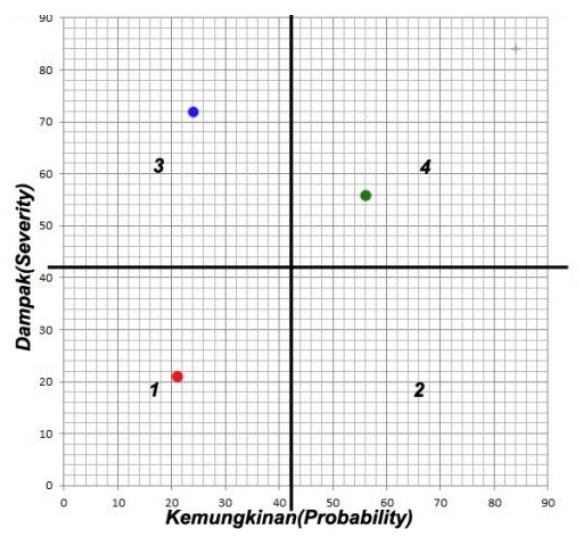

Sumber: Diolah dari Hasil Wawancara

Gambar 2.

\section{Matriks Pengukuran Risiko Operasional}

\section{Ancaman dari Luar}

Ketiga warna titik berwara tersebut menunjukkan posisi masing-masing lembaga amil zakat nasional pada matriks pengukuran risiko, titik warna merah merupakan yatim mandiri, titik warna biru merupakan nurul hayat dan titik warna hijau merupakan YDSF, angka satu hingga empat menunjukkan letak kuadran pada matriks pengukuran risiko tersebut.

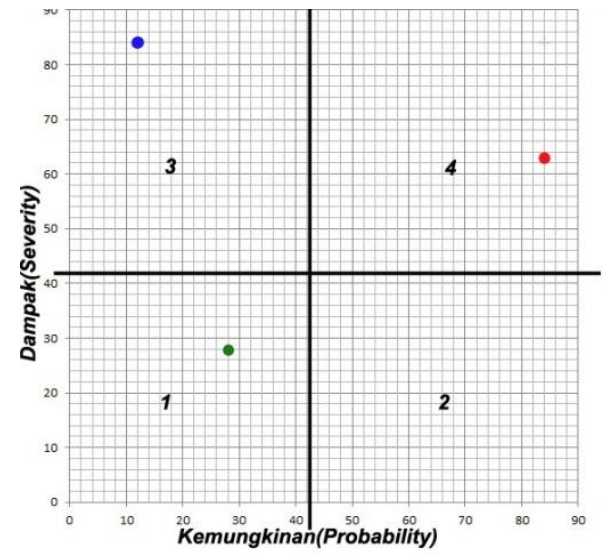

Sumber: Diolah dari Hasil Wawancara

Gambar 3.

Matriks Pengukuran Risiko Operasional Kegagalan Sistem

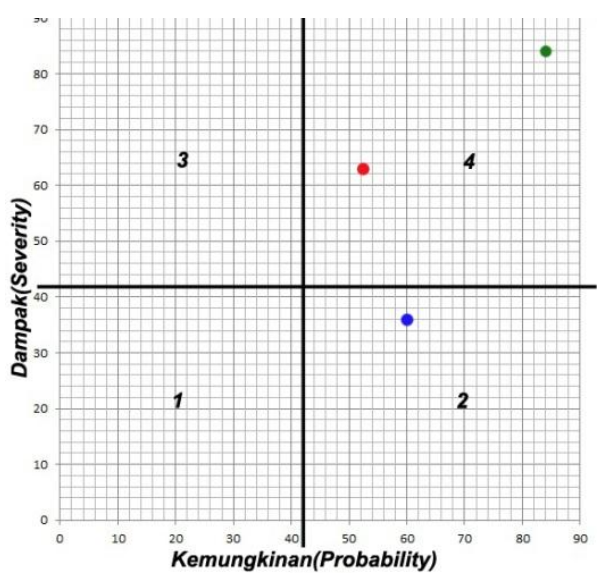

Sumber: Diolah dari Hasil Wawancara

Gambar 4.

Matriks Pengukuran Risiko Operasional Kegagalan Mengelola Manusia

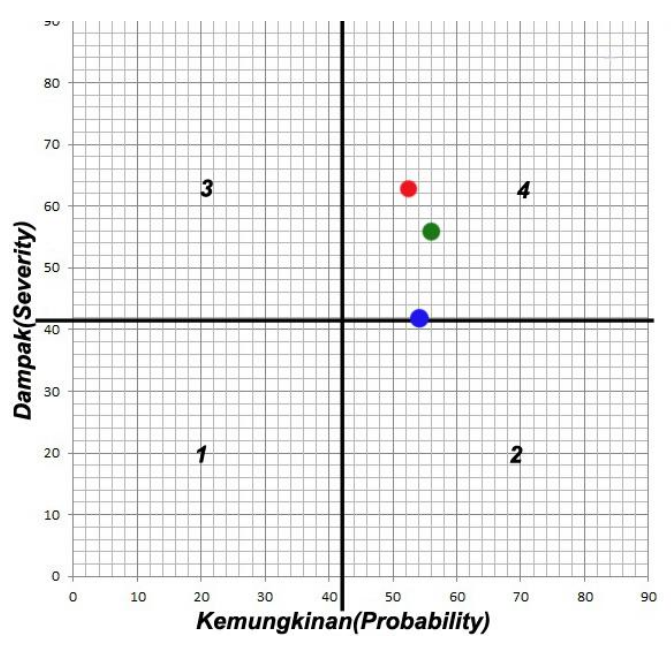


Sumber: Diolah dari Hasil Wawancara

Gambar 5.

\section{Matriks Pengukuran Risiko Operasional Kegagalan Proses Internal}

Pengolahan risiko pada lembaga amil zakat nasional terhadap 14 risiko yang telah teridientifikasi berdasarkan hasil wawancara adalah sebagai berikut:

1. Risiko target yang tidak tidak terpenuhi. Ketika target pengumpulan dana zakat tidak terpenuhi setiap tahunnya otomatis penyaluran dana yang sudah direncanakan sebelumnya dapat terganggu maka tindakan yang diambil oleh lembaga amil zakat yatim mandiri adalah dengan melakukan pengelolaan terhadap penyaluran dana zakat nantinya.

2. Risiko kepatuhan syariah yang tidak terpenuhi.

Apabila kepatuhan syariah tidak terpenuhi dampak paling buruk bagi lembaga amil zakat nasional adalah pencabutan izin dan hilangnya pengakuan oleh BAZNAS. Penanganan risiko yang dilakukan oleh yatim mandiri agar kepatuhan syariah dapat terpenuhi adalah dengan cara mengkonsultasikan setiap program baru kepada dewan syariah agar sesuai dengan regulasi yang telah ada.

3. Risiko sistem komputer yang bermasalah.

Penanganan yang dilakukan oleh yatim mandiri apabila sistem komputer bermasalah adalah dengan memiliki antivirus, dengan dilakukannya hal tersebut maka data yang dimiliki dapat terlindungi.

4. Risiko persaingan dengan LAZNAS lain Untuk mengatasi risiko persaingan dengan LAZNAS lain yatim mandiri mengaku hanya perlu waspada saja, karena bagi mereka lembaga amil zakat nasional lain merupakan mitra, tidak pantas apabila mereka disebut bersaing.

5. Risiko supplier yang terbatas.

Untuk mengatasi risiko supplier yang terbatas lembaga amil zakat nurul hayat memiliki safety stock, dimana nurul hayat memiliki stock barang, barang tersebut antara lain seperti computer atau apapun yang memiliki kemungkinan untuk rusak atau digantikan, karena apabila barang barangtersebut rusak maka karyawan tidak dapat bekerja.

6. Risiko cyber error.

Untuk mengatasi cyber error lembaga amil zakat nasional nurul hayat memiliki programmer yang mengkontrol seluruh aktifitas yang berhubungan dengan internet, serta memiliki rumah-rumah server kosong yang sewaktu waktu dapat digunakan apabila terjadi masalah pada server yang lama, hal ini menjadi penting ketika kegiatan suatu lembaga amil zakat nasional sudah terotomatisasi dengan internet.

7. Risiko pengajuan cuti yang tidak sesuai peraturan.

Untuk mengatasi risiko pengajuan cuti karyawan, nurul hayat selalu 
mengingatkan karyawannya melalui slip gaji terkait sisa cuti yang dapat di ambil dan peraturan terkait pengambilan cuti, pengajuan cuti hanya dapat diajukan $\mathrm{H}-3$ agar dapat diproses.

8. Risiko pengajuan dana kesehatan yang tidak sesuai peraturan.

Untuk mengatasi risiko pengajuan dana kesehatan, nurul hayat mewajibkan karyawannya mengumpulkan kuitansi atau nota asli, khusus untuk cabang karena waktu pengiriman nota membutuhkan waktu, nurul hayat mengatasinya dengan menggunakan google form, hal ini karena dana kesehatan dibutuhkan dengan segera oleh karyawannya yang sakit.

9. Risiko pengajuan pelatihan karyawan yang tidak sesuai peraturan.

Untuk mengatasi risiko pengajuan pelatihan karyawan nurul hayat menggunakan google form yang bertujuan untuk mengkontrol rangkaian pelatihan karyawan, di dalamnya terdapat informasi mengenai siapa yang mengikuti pelatihan hingga bagaimana pelatihan tersebut bermanfaat bagi anggota timnya.

10. Risiko prosedur yang tidak berjalan.

Untuk mengatasi risiko prosedur yang tidak berjalan nurul hayat memiliki satu staff control kebijakan yang melakukan kontrol terhadap kebijakan yang telah dirumuskan sebelumnya, apakah kebijakan tersebut telah diterapkan ataukah kebijakan tersebut belum diterapkan, sesuai dengan yang disampaikan oleh Ibu Tantri:

11.Risiko resik, rapi, ringkas, rajin yang tidak terpenuhi.

Untuk mengatasi permasalahan $5 R$ yang tidak terpenuhi, lembaga amil zakat nasional nurul hayat membuat poster kecil dengan nomor yang bisa dihubungi sewaktu waktu, terletak pada tembok dimana pada lokasi tersebut memiliki kemungkinan untuk terjadi pelanggaran $5 R$, sehingga apabila terjadi pelanggaran maka sewaktu waktu nmor tersebut dapat dihubungi untuk di tindak lanjut.

12. Risiko pengambilan donasi yang tidak tepat waktu.

Untuk mengatasi risiko ini lembaga amil zakat nasional YDSF mengatasinya dengan adanya cadangan karyawan yang bertugas mengambil dana zakat dari para donatur, hal ini menjadi penting bagi YDSF karena apabila dana zakat tidak dapat diterima maka penyaluran akan terhambat.

13. Risiko edukasi masyarakat yang kurang mengenai zakat.

Untuk membangun minat masyarakat dalam berzakat YDSF melakukan edukasi kepada masyarakat melalui sekolah-sekolah, sasarannya adalah anak-anak muda, karena hal ini berkaitan dengan regenerasi para muzaki, apabila kesadaran masyarakat untuk berzakat kurang maka akan berdampak buruk terhadap 
pengelolahan zakat oleh lembaga amil zakat tersebut.

14. Risiko perkembangan teknologi.

Untuk mengatasi perkembangan teknologi YDSF mengantisipasinya dengan pembuatan aplikasi yang dapat mempermudah masyarakat dalam berzakat, namun aplikasi ini masih dalam proses pembuatan

\section{Simpulan}

Kesimpulan tersebut diantaranya:

1. Seluruh lembaga amil zakat nasional yang diteliti telah melaksanakan proses manajemen risiko operasional.

2. Pada tahap identifikasi risiko lembaga amil zakat nasional terdapat 14 risiko yang teridientifikasi.

3. Pada tahap pengukuran dan evaluasi risiko yatim mandiri memiliki kemungkinan dan dampak risiko operasional kegagalan sistem dan kegagalan proses internal yang paling besar, YDSF memiliki kemungkinan dan dampak risiko operasional ancaman dari luar dan kegagalan mengelola manusia yang paling besar.

4. Pada tahap pengelolaan risiko terdapat dua strategi penanganan risiko yaitu preventif dan mitigasi, berdasarkan kasil wawancara maka dapat diketahui bahwa 13 dari 14 risiko yang telah teridientifikasi menggunakan strategi preventif dalam penanganannya dan haya satu risiko yang menggunakan strategi mitigasi dalam menangani risiko.

\section{DAFTAR PUSTAKA}

Alijoyo, Antonius Alijoyo. 2006. Enterprise Risk Management: Pendekatan

Praktis. Edisi kedua. Jakarta: PT. Ray Indonesia

Amrullah, dan Haris Budiyono. 2004. Pengantar Manajemen. Yogyakarta: Graha IImu

Ascarya dkk. 2016. Merancang Manajemen Risiko Pengelolaan Zakat, Jakarta: Departemen Ekonomi dan Keuangan Syariah Bank Indonesia

Bank Indonesia. 2016. Pengelolaan Zakat yang Efektif: Konsep dan Praktik di Berbagai Negara Seri Ekonomi dan Keuangan Syariah. Jakarta: Departemen Ekonomi dan Keuangan Syariah - Bank Indonesia Ghoffar, M 'Abdul. 2009. Tafsir Ibnu Katsir. Jakarta: Pustaka Imam Asy-Syafi'i.

Kementrian Agama Republik Indonesia. 2012. Standar Operasional Prosedur Lembaga Amil Zakat. Jakarta: Kementrian Agama Republik Indonesia

Koontz, Harold dan Heinz Weihrich. 2012. Essentials of Management An International and Leadership Perspective. New Delhi. Tata McGraw-Hill

Kountur, Ronny. 2008. Mudah Memahami Manajemen Risiko Perusahaan. Jakarta: PPM

M. Hanafi, Mamduh. 2012. Manajemen Risiko. Yogyakarta: UPP STIM YKPN Qardawi, Yusuf. 1999 Hukum Zakat. Bandung: Penerbit Mizan. 
Nazir, et al/Jurnal Ekonomi Syariah Teori dan Terapan Vol. 6 No. 11 November 2019: 2236-2251;

MANAJEMEN RISIKO OPERASIONAL PADA LEMBAGA AMIL ZAKAT NASIONAL

Solihin, Ismail. 2009. Pengantar Manajemen. Jakarta: Erlangga

Sugiyono. 2010. Metode Penelitian

Pendidikan. Bandung: Alfabeta

Wahyudi, Imam dkk. 2013. Manajemen

Risiko Bank Islam. Jakarta: Salemba

Empat.

Yin, Robert K. 2015. Studi Kasus Desain \& Metode. Jakarta: PT Raja Grafindo Persada. 